\title{
EVALUATION OF PLUG-IN PARALLEL HEV TOPOLOGIES USING OPTIMAL CONTROL METHODS AND VEHICLE DYNAMICS SIMULATION
}

\section{RASTISLAV TOMAN}

CTU in Prague, Faculty of Mechanical Engineering; Technická 4, Praha 6, 166 07, Czech Republic; rastislav.toman@fs.cvut.cz

\section{JOLANA HEŘMANOVÁ}

CTU in Prague, Faculty of Mechanical Engineering; Technická 4, Praha 6, 166 07, Czech Republic; jolana.hermanova@fs.cvut.cz

\begin{abstract}
Hybrid electric vehicle (HEV) powertrains with parallel topologies are among the frequently used layouts, because of their easy applicability on an existing conventional powertrain, by the addition of hybrid modules with mild, full, or a plug-in capability. This paper investigates three of such parallel HEV topologies: P2, P3, and P4; all in a plug-in variant, to find-out which one performs best. Apart from the topology consideration, one of the other common questions or challenges in HEV development is the ICE concept selection. To address it, the paper combines the three HEV topologies with three technologically different internal combustion engines, all with the same power outputs. Then, all the powertrain and ICE combinations are tested in homologation driving cycles and vehicle dynamics simulation test - different acceleration tests - giving a holistic methodology suitable for thorough HEV topology evaluation, identifying all possible hybridization benefits. To find the maximum $\mathrm{CO}_{2}$ potential, it is convenient to exclude the effect of the energy management control strategy on the $\mathrm{CO}_{2}$ result in a charge sustaining driving cycle; therefore, to use some optimal control method. For this task, the paper compares the Equivalent Consumption Minimization Strategy, that realizes a Pontryagin's minimum principle against the Dynamic Programming optimal control method, which is based on Bellman's principle of optimality. Both control methods are available as a part of GT-Suite 0D/1D/3D multi-physics CAE simulation software, that is used in our whole study.
\end{abstract}

KEYWORDS: HYBRID ELECTRIC VEHICLE, OPTIMAL CONTROL METHOD, ENERGY MANAGEMENT STRATEGY, DYNAMIC PROGRAMMING, ECMS, PONTRYAGIN'S MINIMUM PRINCIPLE, PARALLEL HYBRID POWERTRAIN TOPOLOGY, PLUG-IN HYBRID, VEHICLE DYNAMICS SIMULATION, GT-SUITE

\section{SHRNUTÍ}

Hybridní elektrická vozidla (HEV) v paralelních topologiích patří mezi běžná uspořádání zejména díky snadné aplikovatelnosti ve stávajících pohonných řetězcích přidáním hybridních modulů, a to v různých úrovních hybridizace od mild, full až po plug-in HEV. Tento článek se věnuje třem paralelním topologiím: P2, P3 a P4 v plug-in variantě s cílem jejich celkového porovnání. Kromě výběru topologie hybridního vozidla je také častou otázkou výběr konceptu spalovacího motoru vhodného pro použití v hybridním vozidle. Abychom se na tuto otázku pokusili odpovědět, porovnáváme v této práci tři topologie hybridních pohonů se třemi technicky různými spalovacími motory o stejném maximálním výkonu. Všechny varianty jsou simulovány v homologačních jízdních cyklech a dalších dynamických testech, které by měly poskytnout ucelenou metodologii pro kompletní porovnání hybridních topologií a identifikovat možné prínosy hybridizace. Při hledání maximální úspory $\mathrm{CO}_{2}$ je vhodné omezit vliv řídící strategie na výsledné hodnoty $\mathrm{CO}_{2} \mathrm{v}$ "charge sustaining" módu použitím některé z optimálních metod řízení. Proto tato práce porovnává ECMS strategii, která je založena na Pontryaginově minimálním principu a metodu dynamického programování založené na Bellmanově principu optimality. Obě metody jsou dostupné jako součást 0D/1D/3D multi-fyzikálního simulačního softwaru GT-Suite, který je v celé studii využíván.

KLIČOVÁ SLOVA: HYBRIDNÍ ELEKTRICKÉ VOZIDLO, OPTIMÁLNI STRATEGIE ŘíZENÍ, ŘíZENÍ ENERGETICKÝCH TOKU゚ VE VOZIDLE, DYNAMICKÉ PROGRAMOVÁNÍ, ECMS, PONTRYAGINU゚V MINIMÁLNII PRINCIP, TOPOLOGIE PARALELNÍHO HYBRIDNIIHO HNACIHO ÚSTROJI, PLUG-IN HYBRID, SIMULACE DYNAMIKY VOZIDLA, GT-SUITE 


\section{INTRODUCTION}

The current mandatory fleet-wide average emission target in $\mathrm{EU}$ - set to $95 \mathrm{grams}$ of $\mathrm{CO}_{2} / \mathrm{km}$ starting with 2020 "phase-in" period and following full application from 2021 [1] pushes the automotive industry into the realm of powertrain electrification. A fleet-wide electrification, either by pure electric vehicles (EV), or by hybrid electric vehicles (HEV), brings the obvious economic implications, especially the higher development and production costs.

The US and EU OEMs try to address these economic implications mainly by adopting the plug-in HEV powertrains (PHEV), combined with parallel topologies. The popularity of plug-ins from the side of OEMs is caused by two factors: first is, that the low average emission targets indirectly push for them; the second then, that a plug-in size battery allows for higher electrical power output and "fun-to-drive" factor of these vehicles. The parallel HEV topologies then give a great variety of options - usually in a form of hybrid modules applied on a conventional powertrain (ICEV) - allowing for relatively small changes in already existing powertrains, and help this way to manage development costs (especially compared to a pure EV powertrain, or more "HEVtailored" solutions) and reduce complexity at the OEM.

However, there are many technical challenges that need to be addressed in the early development stages of any new $\mathrm{HEV}$ powertrain. These revolve mainly around the overall $\mathrm{CO}_{2}$ emission reduction potential, of the chosen parallel topology, different internal combustion engine (ICE) technology, or battery size, but also - when talking about the PHEV solutions - the performance gains in dynamic tasks.

The one variable affecting the $\mathrm{CO}_{2}$ performance of a studied $\mathrm{HEV}$ powertrain and its components is the energy management control strategy. It is therefore ideal to exclude its effects on the overall $\mathrm{CO}_{2}$ results, and ensure a globally optimal solution, when performing this type of study. GT-Suite multi-physics CAE simulation software already contains two built-in optimal control strategies: Dynamic Programming algorithm (DP), and Equivalent Consumption Minimization Strategy (ECMS). DP algorithm solves the highly nonlinear HEV system's behavior, in a globally optimal manner. It is a numerical control method of solving a multi-stage decision-making optimal control problem ([2] or [3]), based on the Bellman's principle of optimality, requiring a priori information about the entire optimization horizon (in our case the entire driving cycle). Although it is not applicable for real-time control for its high computation demand, it can serve as a very good benchmarking tool, exactly according to the needs of our paper. A more computationally efficient option for the energy management strategy is the ECMS algorithm, that realizes the Pontryagin's minimum principle (PMP). Although the ECMS is also an "optimal control method", it is not intrinsically optimal as such [4], meaning it is only optimal locally in each time step, not globally during the whole driving cycle. Keeping the terminology from [4], we could further distinguish between the ECMS and PMP methods: nowadays, the term ECMS is more often used for the online causal method, whereas the PMP term is reserved for the offline non-causal application.

Some implementations of DP were used to study the optimal hybridization level in two parallel HEV topologies in [2], to instruct rule-based energy management strategies in $[5,6]$, to optimize the transmission's shifting strategy in [7], or to study the optimal strategy for a series-parallel Toyota Prius powertrain in [8]. Then, Zeng et al. presented an ECMS implementation as a casual suboptimal method performed online, by using several simplifying assumptions for the equivalence factor based on past and present driving in [9], or Nüesch et al. in [10] extended the Hamiltonian function with a pollutant emissions minimization. There are also some comparative studies of DP vs. PMP performance, one from Yuan et al. [11]. Finally, Zeman et al. [12] present a broad HEV topologies' $\mathrm{CO}_{2}$ comparative study combined with modular simulation models within the GT-Suite simulation platform, using only heuristic control methods.

Our paper is divided into four main chapters, following this introductory chapter 1 . Chapter 2 shows the vehicle data and parameters, together with more details on HEV topologies, and internal combustion engines (ICE). Chapter 3 then presents our benchmarking simulation methodology, different simulation models, and homologation calculations. Chapter 4 is dedicated to the results; and finally, chapter 5 presents some overall conclusions.

\subsection{GOALS OF THE PAPER}

The main objective of our study is to showcase and apply a full development and benchmarking methodology for HEV vehicle powertrains.

This main objective then specifies in two following goals:

- First, to present a sensitivity on a parallel HEV topology type, comparing P2, P3, and P4 variants;

- Second, to test for a synergy effect between the ICE downsizing and powertrain hybridization, comparing three ICE technologies with three different downsizing levels.

The presented methodology consists of vehicle $\mathrm{CO}_{2}$ homologation results (using WLTP methodology), together with some dynamic tasks. These can be easily expanded with other user dynamic tasks, or driving cycles, together with future RDE cycles, or any other real-life user scenarios - if requested. All our simulation tests are carried-out on a C-class vehicle, with the same plug-in size battery, and hence pure electric drive capability (EV mode). 
The additional goals of our paper are:

- To compare the two optimal control methods implemented in GT-Suite;

- To study the ECMS $\mathrm{CO}_{2}$ sensitivity on different heuristic criteria with our HEV powertrains;

- To study the HEV powertrains' performances in some dynamic tasks (different acceleration tests, and maximum vehicle speed).

\section{VEHICLE DATA AND PARAMETERS}

TABLE 1: Main vehicle parameters

TABULKA 1: Hlavní parametry vozidla

\begin{tabular}{|lcc|}
\hline Base vehicle mass & 1240 & {$[\mathrm{~kg}]$} \\
\hline Frontal area & 2.20 & {$\left[\mathrm{~m}^{2}\right]$} \\
\hline Drag coefficient & 0.31 & {$[-]$} \\
\hline Tire rolling resistance factor & 0.009 & {$[-]$} \\
\hline Tire rolling radius & 307 & {$[\mathrm{~mm}]$} \\
\hline
\end{tabular}

We have chosen a C-class vehicle with front-wheel drive (FWD) as a baseline for all the simulations in our study. Table 1 summarizes its main vehicle parameters (base vehicle mass is without ICE). This baseline vehicle is compared to the three parallel HEV topologies (figure 1). The first two of the investigated HEV topologies - P2 and P3 - are FWD, the P4 offers the AWD (all-wheel drive) capability, although aspects such as climbing ability are not considered. P2 and P4 solutions are especially common nowadays, with P2 being probably cheaper and easier to integrate into an existing conventional powertrain (depending on the original vehicle that is hybridized). The additional masses are then in Table 2: HEV masses include high voltage battery mass of $110 \mathrm{~kg}$, EM mass of $35 \mathrm{~kg}$, and estimated masses for transmission adjustments, and additional clutches (KO clutch for P2; P4 clutch).

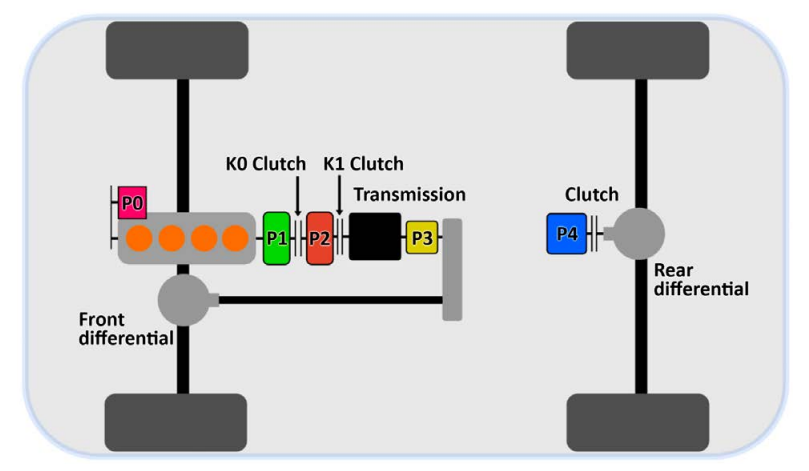

FIGURE 1: Parallel HEV topologies components' layout OBRÁZEK 1: Uspořádání komponentů v paralelních HEV topologiích
High voltage battery is based on a Samsung SDI lithium ion prismatic battery cells with capacity of $37 \mathrm{Ah}$, and nominal voltage of $3.7 \mathrm{~V}$. The battery system is then configured into $104 s 1 p$ (104 cells in series, one in parallel), giving the total energy capacity of $14.8 \mathrm{kWh}$ at nominal voltage of $400 \mathrm{~V}$.

TABLE 2: Additional masses of ICE and HEV components

TABULKA 2: Dodatečné hmotnosti spalovacích motorů a hybridních komponentů.

\begin{tabular}{|lll|}
\hline $2.0 \mathrm{NA}$ & 130 & {$[\mathrm{~kg}]$} \\
\hline $1.5 \mathrm{TC}$ & 120 & {$[\mathrm{~kg}]$} \\
\hline $1.0 \mathrm{TC}$ & 110 & {$[\mathrm{~kg}]$} \\
\hline P2 HEV & 165 & {$[\mathrm{~kg}]$} \\
\hline P3 HEV & 150 & {$[\mathrm{~kg}]$} \\
\hline P4 HEV & 190 & {$[\mathrm{~kg}]$} \\
\hline
\end{tabular}

The powertrain hybridization ratio $\left(P_{I C E} / P_{E M}\right)$ is kept fixed: three ICE concepts with power output of around $135 \mathrm{~kW}$ are combined with the same electric motor (EM) of $54 \mathrm{~kW}$ (Table 3). The BSFC and efficiency maps are displayed in figure 2 .

TABLE 3: ICE and EM main parameters

TABULKA 3: Hlavní parametry spalovacích motorů a elektromotoru.

\begin{tabular}{|lccccc}
\hline & $\begin{array}{c}\text { Maximum } \\
\text { Torque } \\
{[\mathrm{Nm}]}\end{array}$ & $\begin{array}{c}\text { Maximum } \\
\text { Power } \\
{[\mathrm{kW}]}\end{array}$ & $\begin{array}{c}\text { Speed } \\
\text { Limit } \\
{[\mathrm{RPM}]}\end{array}$ & $\begin{array}{c}\text { BSFC } \\
{[\mathrm{g} / \mathrm{kWh}]}\end{array}$ & $\begin{array}{c}\text { Efficiency } \\
{[\%]}\end{array}$ \\
\hline 2.0 NA & 227 & 137 & 6500 & 224.9 & - \\
\hline $1.5 \mathrm{TC}$ & 245 & 135 & 6000 & 237.7 & - \\
\hline $1.0 \mathrm{TC}$ & 245 & 135 & 6000 & 238.5 & - \\
\hline EM & 141 & 54 & 8000 & - & 92.9 \\
\hline
\end{tabular}

The EM presents a classical high torque - high efficiency synchronous traction machine with permanent magnets. It is downscaled from GKN's commercial AF130 traction motor with $130 \mathrm{~kW}$, keeping the same efficiency map.

Three spark ignition, direct injection ICE concepts represent different levels of ICE downsizing:

- naturally aspirated $2.0 \mathrm{~L}$ four cylinder $(2.0 \mathrm{NA})$;

- turbocharged $1.5 \mathrm{~L}$ three cylinder $(1.5 \mathrm{TC})$ with a BMEP of 20.5 bar;

- highly turbocharged $1.0 \mathrm{~L}$ three cylinder $(1.0 \mathrm{TC})$ with a BMEP of 31.0 bar. 

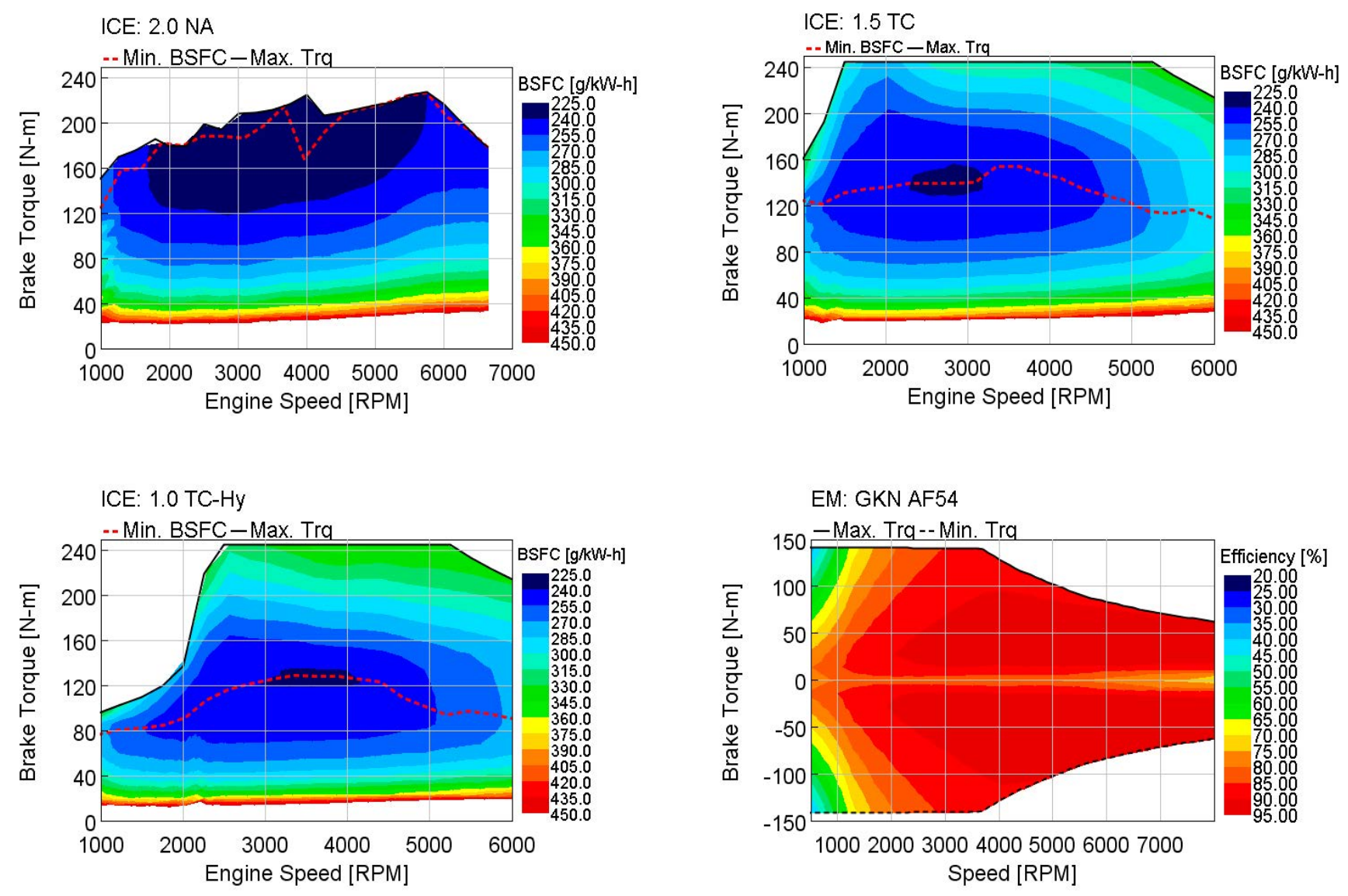

FIGURE 2: BSFC maps of ICE concepts; EM efficiency map

OBRÁZEK 2: Měrná spotřeba konceptů spalovacích motorů; mapa účinnosti elektromotoru

Turbocharged concepts use a single-stage charging system with charge-air-cooler, lowered compression ratios (compared to $2.0 \mathrm{NA}$ ), together with intake and exhaust variable valve timing (VVT); the $2.0 \mathrm{NA}$ concept uses VVT only on the intake side.

The 2.0 NA concept represents a state-of-the-art direct injection naturally aspirated engine, with the best BSFC from all concepts. A great advantage - in comparison to the turbocharged concepts - should be its relative simplicity, reliability, and therefore also cost. The $1.5 \mathrm{TC}$ concept's performance and technology represent a standard in current downsizing era. The 1.0 TC should be the best from the packaging and mass viewpoint. However, this is offset by higher price, and poorer low-end-torque performance.

All three ICE concepts are matched to a distinct six-speed transmission with progressive and sporty gear ratios (figure 3). The transmissions' efficiencies are taken from a similar production transmission, the other driveline efficiencies are kept constant. P4 variant adds a single-speed transmission, again with constant efficiency, and total gear ratio of 6.2 (transmission gear ratio of 2.48 and differential gear ratio of 2.5), that allows for the EM use below $150 \mathrm{~km} / \mathrm{h}$, then it is de-clutched.

\section{SIMULATION METHODOLOGY}

There are two basic vehicle simulation methods in GT-Suite: a kinematic method, and a dynamic method. Our simulation methodology fully exploits these two different modelling options, together with the modularity of GT-Suite simulation software package.

The first one - backward kinematic - calculates the ICE/EM operating point from the imposed vehicle speed, and from the vehicle external loads (optionally imposing ICE/EM speed and load, then called a forward kinematic method).

The second method - dynamic - performs the physical sequence of actions as in the real-life vehicle with a driver: driver operates the accelerator and brake pedals, and shifts gears; his commands are then interpreted in an ECU model, and sent to the plant models (ICE, EM, etc.), the same way as in a real vehicle, resulting in vehicle acceleration. 

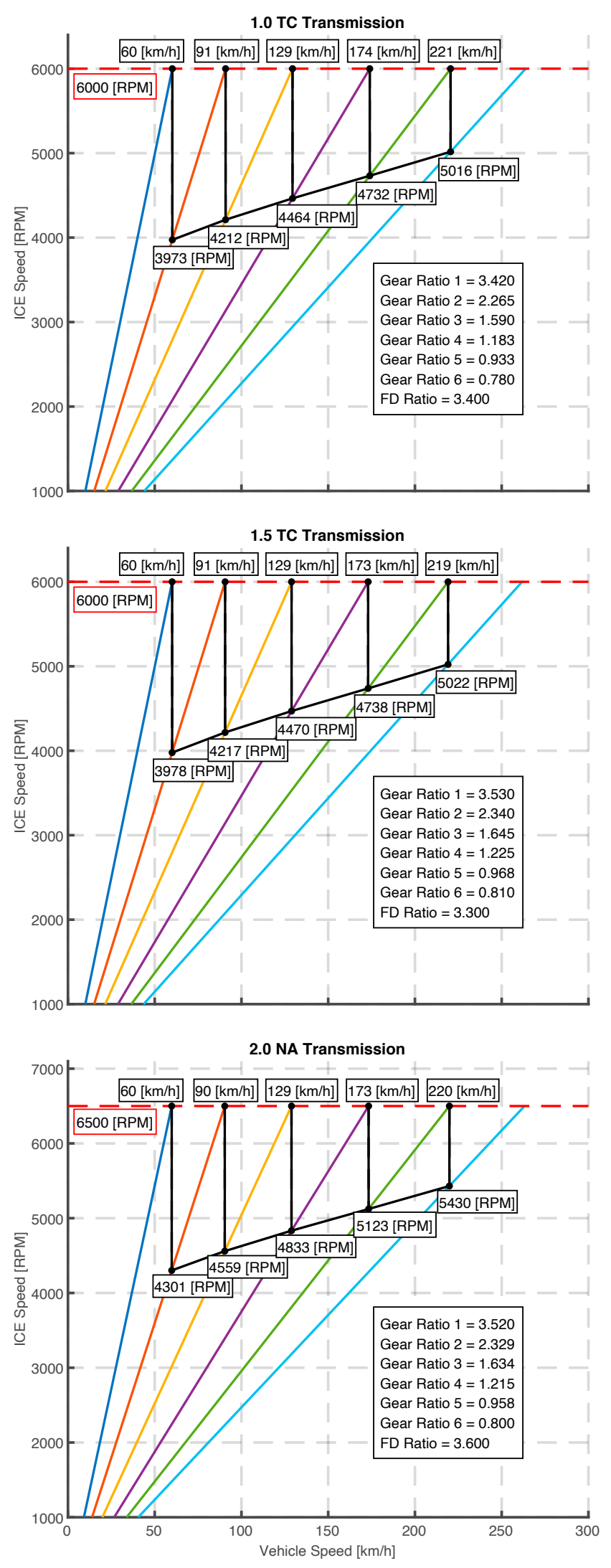

FIGURE 3: Transmission layouts for all three ICE concepts OBRÁZEK 3: Pilové diagramy tří použitých převodovek
The next chapters from 3.1. to 3.5. give a comprehensive look on the use of the two vehicle simulation methods in our studies: 3.1. shows how we work with these different simulation models; then we discuss the two optimal control methods (in 3.2. and 3.3.) with some heuristic criteria (in 3.4.); and 3.5. finally shows the different simulation test, that serve either for benchmark studies, or for vehicle homologation results.

\subsection{SIMULATION MODELS}

There are two models for each HEV powertrain topology: a dynamic model (DYN), and a kinematic model (KIN). Both are built using interchangeable modules or sub-systems (e.g. ICE model, EM model, HV-Battery model etc.) for each simulation method, with the same database containing the vehicle data and parameters from chapter 2 . This combined approach of using modular models in combination with parameter database aids the general use and simulation work, together with simple possible replacement of some sub-system with a new one, that for instance accounts for more detailed physical behavior, or control logic. These changes can be then done easily and quickly for each HEV powertrain model.

KIN models are used for the ICEV CO $\mathrm{CO}_{2}$ results simulation and since the optimal control methods - that will be discussed in next chapters - are coupled with the kinematic method, also the "Charge sustaining" (CS) $\mathrm{CO}_{2}$ results. DYN models are then used for the E-range estimation and all other vehicle dynamics studies.

Driveline model in GT-Suite is built by the combination with 1D inertias with either rigid or compliant connections. The vehicle data in our simulation models (KIN and DYN) are then mostly map based.

High voltage battery is simulated as a resistive electricalequivalent model with separate open-circuit voltage, and internal resistance maps for charge and discharge.

Then, combustion engines are simulated through map-based models with fuel consumption maps, and torque limits dependent on rotational speed. This map-based approach for the ICE simulation does not capture well the dynamic effects in transient behavior, which is especially apparent for the turbocharged ICE concepts at vehicle dynamics test. On the other hand, the map-based approach is very simple and giving fast simulation times, and its accuracy in the driving cycle simulation depends on ICEs relative power to the total vehicle loads (smaller ICE leads to more demanding transient behavior). The problem with ICE transients can be mitigated with additional torque rise limit maps (in $[\mathrm{Nm} / \mathrm{s}]$ ), or by more detailed physical ICE sub-system using either full 1D or simplified 1D fast-running model. However, these are not used in our study. 
The EM model is also map-based with an efficiency map, and torque limits dependent on the rotational speed. Thanks to the very fast EMs transient response, the map-based approach is accurate enough.

Finally, also the transmission models are map-based (together with other gear ratios), with efficiencies that are taken from a similar production manual transmission, and maps dependent on input torque, rotational speed, and engaged gear.

\subsection{DYNAMIC PROGRAMMING CONTROL METHOD IN GT-SUITE}

Bellman's principle of optimality used in the DP control method states [13]: "An optimal policy has the property that whatever the initial state and initial decision are, the remaining decisions must constitute an optimal policy with regard to the state resulting from the first decision. A complex multistage optimal problem can be divided into a series of single-stage optimal problem. Each single-stage optimal problem is solved by optimal solutions, and cost function is minimized according to a sequence of decisions for each step."

DP algorithm implementation within GT-Suite is described in more detail in [3], therefore, we will reproduce only some of the most important concepts here.

The DP cost function $J$ is defined by the equation 1, where:

- $g_{N}\left(x_{N}\right)$ represents the final cost, and additional Terminal State Penalty $T_{N}\left(x_{N}\right)$, that partially constrains the final state;

- Function $L_{k}\left(x_{k}, u_{k}\left(x_{k}\right)\right)$ represents the cost of applying control $\mu_{k}\left(x_{k}\right)$ at $x_{k}$ according to the control problem's Hamiltonian function;

$J_{\pi}\left(x_{0}\right)=g_{N}\left(x_{N}\right)+T_{N}\left(x_{N}\right)+\sum_{k=0}^{N=1} L_{k}\left(x_{k}, u_{k}\left(x_{k}\right)\right)+p_{k}\left(x_{k}\right)$

$T_{N}$ is then defined in equation 2, with its Terminal State Penalty Weight $\gamma$, and Terminal State Penalty Exponent $\beta$. Penalty function $p_{k}\left(x_{k}\right)$ enforces the state constraints for $k=0,1, \ldots$, $N-1$. Equation 3 gives the definition of $p_{k}\left(x_{k}\right)$, with Penalty Function Weight $\lambda$, and Penalty Function Exponent $\alpha$.

Battery SOC related units here are the SOC limits $S O C_{\max }$ and $S_{\text {OC }}$ min Target Battery SOC SOC $C_{\text {target, }}$ and the discretized SOC points $S O C_{\text {grid }}$, that is used only in the equation 2.

$T_{N}=\gamma\left(S O C_{\text {grid }}-S O C_{\text {target }}\right)^{\beta}$

$p(S O C)=\lambda\left(\frac{S O C(t)-S O C_{\text {target }}}{\frac{\left(S O C_{\max }-S O C_{\min }\right)}{2}}\right)^{\alpha}$
The optimal policy minimizes $J_{\pi}\left(x_{0}\right)$ for all admissible policies meaning control inputs (e.g. powertrain mode, electrical motor torque, transmission gear etc.), where $\pi$ is the set of all of them (equation 4).

$J^{*}\left(x_{0}\right)=\min _{x \in \pi} J_{\pi}\left(x_{0}\right)$

Based on the principle of optimality, DP evaluates the optimal cost-to-go function $J_{\pi}\left(x^{i}\right)$ - or optimal control trajectory - at every node in discretized grid points $\left(x_{k}{ }^{i}\right.$ is one of the state variables, at a node with time index $k$ and state index $i$ ), with SOC being the state variable (DP implementation in GT-Suite version v2020 uses only one state variable - SOC). DP then proceeds backward in time, with equation 5 yielding the end cost calculation, and equation 6 the cost calculation for steps $k=0,1, \ldots, N-1$.

$J_{N}\left(x^{i}\right)=g_{N}\left(x^{i}\right)+T_{N}\left(x^{i}\right)$

$J_{k}\left(x^{i}\right)=\min _{u_{k} \in U_{k}}\left\{L_{k}\left(x^{i}, u_{k}\right)+p_{k}\left(x_{k}\right) \ldots+J_{k+1}\left(f_{k}\left(x^{i}, u_{k}\right)\right)\right\}(6)$

The right-hand side of equation 6 is minimized at each state-time node, for each $x_{k}^{i}$ leading to the optimal control policy. However, $J_{k+1}(x)$ is only evaluated for discretized points; output function $f_{k}\left(x^{i}, u_{k}\right)$ must be interpolated, since the state output is continuous in the state space, and so generally does not coincide with the state grid nodes. This introduces numerical errors and bounds the solution's accuracy to the discretization of the state space, and control inputs. If the discretization resolution increases, also the DP's accuracy increases. Though, also the computation load is higher. Outputs from equations 5 and 6 create the optimal control map, from which the algorithm derives the optimal control trajectory. A challenge for each new DP simulation problem is to understand the results' sensitivity on state variable resolution and limits ( $\min / \max$ values); sensitivities on four penalty parameters from equations 2 $(\beta, \gamma)$ and $3(\alpha, \lambda)$; and sensitivity on control variables' discretization. This process can be very time consuming, but necessary.

\subsection{ECMS CONTROL METHOD IN GT-SUITE}

The equivalent consumption in ECMS refers in its basic form in equation 7, to converting the battery power $P_{b}$ to an equivalent fuel power by using a non-dimensional equivalence factor $s$, and adding it to an actual fuel power $P_{f}[4]$.

$H(t, s, u)=P_{f}(t, u)+s(t) \cdot P_{b}(t, u)$

This equivalence factor $s$ depends on the driving cycle, and on battery initial/final conditions; it represents the cost of recharging 
the battery power in future (by regenerative braking or ICE charging). Therefore, to set the equivalence factor accurately, the future conditions (e.g. the driving cycle) need to be known beforehand (either for the online or offline applications).

ECMS algorithm implementation in GT-Suite calculates the equivalent fuel consumption using the equation 8 , combining the equivalence factor $s$, with a penalty function $p$. The equivalence factor $s$ can generally vary during the driving cycle, however in this implementation it is used as a constant.

The penalty function $p$ (equation 9) helps to keep the SOC within the certain limits and thus reach the final SOC state at the end of the simulated driving cycle, where the penalty function's exponent $\alpha$ changes it's "aggressiveness" with SOC value deviating from SOC $_{\text {target }}$.

The user then controls the ECMS by varying these two parameters: equivalence factor $s$, and the penalty function exponent $\alpha$ (Note: the penalty function exponent $\alpha$ is not related to the one used in DP and can generally have different integer values). To simulate a "charge-sustaining" (CS) cycle, the "optimal" value of the $s$ factor must be found for the chosen hybrid powertrain and its initial/final conditions.

$$
\begin{aligned}
& \dot{m}_{e q v}(t)=\dot{m}_{f}(t)+\frac{S}{Q_{L H V}} \cdot P_{b a t t}(t) \cdot p(S O C) \\
& p(S O C)=1-\left(\frac{S O C(t)-S O C_{\text {target }}}{\frac{\left(S O C_{\max }-S O C_{\min }\right)}{2}}\right)^{\alpha}
\end{aligned}
$$

We could say, that based on the terminology mentioned in the introductory chapter from [4], this GT-Suite's implementation could be called a PMP method, since it works offline, and in combination with iterative approach to find the equivalence factor $s$. Also, the nature of this implementation - numerical minimization of the equivalent fuel consumption in each time step - should lead to an "aggressive" behavior and results close to DP control method Yuan et al. [11] presented a difference only of $0.4 \%$ between the two methods.

\subsection{ADDITIONAL HEURISTIC CONDITIONS FOR OPTIMAL CONTROL METHODS}

When using either one of the optimal control algorithms above, it is suitable to have some additional options to "guide" the algorithm apart from the basic limits, such as battery or EM power limits etc. These can represent real-life scenarios and limits, that cannot be imposed by the simple control limits: e.g. forced ICE starts to account for heating of the catalytic converter, limiting conditions on the use of EV mode to ensure more predictable powertrain mode switching behavior, or imposing the limit conditions on maximum allowable gear when optimizing the gear shifting strategy. This way the user can get some idea of an impact of these criteria or conditions on the global FC (fuel consumption) optima.

In the case of ECMS, this can further improve its results - and in some cases ensure method's convergence to CS result, which is not guaranteed (as will be shown in a chapter 4.5). When we have a look on the WLTC and CS simulation, the local ECMS's optimality leads to an almost continual battery charge roughly in the first half of the cycle, followed by discharge during the second half (figure 4, blue line). This results in sub-optimal fuel consumption for the CS cycle and PHEV powertrain from the global point of view.

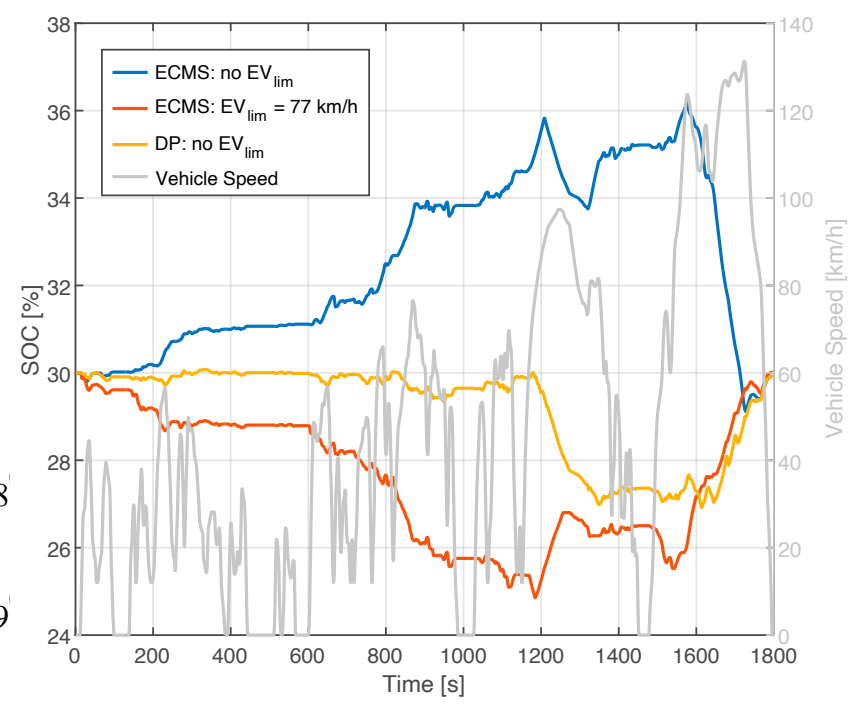

FIGURE 4: SOC comparison of DP vs. ECMS with $E V_{\text {lim }}$ heuristic parameter turned on/off in CS WLTC

OBRÁZEK 4: Porovnání průběhů SOC algoritmů DP a ECMS s heuristickým parametrem $E V_{\text {lim }}$ zapnutým/vypnutým v "charge sustaining" módu jízdního cyklu WLTC

This specific problem can be mitigated by the additional heuristic criteria, that limits the maximum vehicle speed, when the electric motor can act as a "primary mover" $\left(E V_{\text {lim }}\right)$. Above this limit, the electric motor can only fulfill the load point shifting function. Similar methods are listed in [4]. The addition of $E V_{\text {lim }}$ changes the "charge sustaining equivalence factor $s$ ", and also affects the overall powertrain behavior: the battery discharges in the first phases of the cycle, and charges in the later phases, improving the overall fuel consumption (figure 4, green line). Red line in figure 4 represents the SOC obtained with the DP algorithm.

\subsection{SIMULATION TYPES AND $\mathrm{CO}_{2}$ HOMOLOGATION CALCULATIONS}

Since one of the goals of this paper is to give a comprehensive benchmarking study of the three HEV topologies combined with three representatives of ICE downsizing level, here we 
enumerate all simulation types and calculations, whose results will be presented in the next result chapter:

- First, there are two simulation tasks, that use KIN models: ICEV $\mathrm{CO}_{2}$ and $\mathrm{CS} \mathrm{CO}_{2}$ (the latter combined with the two optimal control strategies);

- Second, the All Electric Range (AER) simulations using DYN models;

- Third, homologation $\mathrm{CO}_{2}$ can be calculated from AER and $\mathrm{CS} \mathrm{CO}_{2}$ results, using the utility factor (UF) according to the WLTP homologation procedure - brief description follows;

- Fourth and final are the vehicle dynamics simulations using DYN models.

$\mathrm{CO}_{2}$ homologation procedure of hybrid vehicles (OVC-HEVs Off-Vehicle Charging Hybrid Electric Vehicles) according to WLTP includes mainly CS, "Charge Depleting" (CD), and AER test [14]. The final combined WLTP fuel consumption $\left(F C_{\text {WLTP }}\right)$ is calculated from CS and CD consumptions, and UF corresponding to the AER, according the equation 10.

$F C_{W L T P}=\sum_{j=1}^{k}\left(U F_{j} \times F C_{C D, j}\right)+\left(1-\sum_{j=1}^{k} U F_{j}\right) \times F C_{C S}$

The fractional utility factor $U F_{j}$ is determined by the equation 11 for a distance $d_{j}$ driven at the $j^{\text {th }}$ period of the WLTC: $C_{i}$ is a set of coefficients determined by the WLTP standard, and $d_{n}$ represents a normalized distance.

$U F_{j}\left(d_{j}\right)=1-\exp \left\{-\left(\sum_{i=1}^{k} C_{i} \times\left(\frac{d_{j}}{d_{n}}\right)^{i}\right)\right\}-\sum_{l=1}^{j-1} U F_{l}$

The All Electric Range represents a distance driven from fully charged battery, until the WLTC phase, when the engine first starts.

\section{SIMULATION RESULTS}

The WLTP requires a $\mathrm{CS}$, and $A E R$ tests for $\mathrm{CO}_{2}$ or fuel consumption evaluation. Since the analyzed powertrains are all PHEV type, the CS driving cycle initial and target SOC values are set to $30 \%$, which would correspond to a usual PHEV battery use: when the battery is charged, the vehicle uses mostly EV mode; then if the SOC level is low (usually around $20-30 \%$ SOC) it switches to HEV mode.

During the entire CS test all three topologies can use the ICE load-point-shifting (LPS) in HEV mode (in case of P4 it is "through-the-road"), together with EV mode. The optimal use of EV to HEV mode switching, and LPS is determined by the DP or ECMS control algorithms, switching the ICE off in the EV mode.
The AER tests start at SOC of $96 \%$, the AER test stops then at $35 \%$. Similarly, the vehicle dynamics tests start with full battery (HEV and EV tests), disregarding any derating behavior of the electrical components.

Regarding the gear shifting strategy, all the sets of results, except for 4.3, use shifting strategy generated by the WLTP. The sensitivity in 4.3 compares the WLTP strategy with the "DP-optimized" shifting, only for the P2 topology.

The combination of $\mathrm{CO}_{2}$ homologation simulations and vehicle dynamics tasks presents a full development and benchmarking methodology for HEV powertrains comparison. The results show the sensitivities on a topology type and a synergy effect between the ICE downsizing and powertrain hybridization. The vehicle dynamic tests results further show the importance of holistic approach to the optimization of these powertrains.

\subsection{ICEV SENSITIVITY ON ICE TECHNOLOGY}

This first ICEV powertrain sensitivity on different ICE concepts (Table 4) reveals an anticipated fact, that the downsized engines provide better fuel economy in homologation driving cycles. Higher ICE downsizing levels achieve lower fuel consumption and $\mathrm{CO}_{2}$ production.

TABLE 4: Fuel consumption and $\mathrm{CO}_{2}$ sensitivity on different ICE concepts TABULKA 4: Spotřeba paliva a produkce $\mathrm{CO}_{2}$ pro různé koncepty spalovacích motorů
ICE

\begin{tabular}{|l|}
\hline $2.0 \mathrm{NA}$ \\
\hline $1.5 \mathrm{TC}$ \\
\hline $1.0 \mathrm{TC}$ \\
\hline
\end{tabular}

FC [L/100km]

6.115

5.777

5.251
$\mathrm{CO}_{2}$ $[\mathrm{g} / \mathrm{km}]$ 139.42 131.72 119.72

\subsection{OVERALL FC/ $/ \mathrm{CO}_{2}$ RESULTS}

\section{(HEV TOPOLOGIES VS. ICE CONCEPTS)}

Table 5 shows the overall results of all three PHEV topologies, combined with the three ICE concepts: CS mode and combined values, together with $A E R$, UF, and $\Delta \mathrm{CO}_{2}$ potential compared to respective ICEV concepts. The CS mode results were simulated using DP control method, with the SOC resolution $\left(S O C_{\text {grid }}\right)$ of $1 \%$ (101 SOC levels), with $E V_{\text {lim }}$ parameter turned off.

First main observation is that the $\mathrm{P} 4$ topology has the biggest overall homologation $\mathrm{CO}_{2}$ potential $\left(\Delta \mathrm{CO}_{2}\right.$ in the last column in table 5), followed by P2, and P3 topologies. The same applies for the AER values, that dictate the UF then used for the combined homologation $\mathrm{FC} / \mathrm{CO}_{2}$ calculation (equations 10 and 11 , with $\mathrm{CD}$ mode $\mathrm{gCO}_{2} / \mathrm{km}$ equal to zero).

Considering that the P3 and P4 topologies work in a very similar way, the AER potential and subsequent combined $F C$ results are 
TABLE 5: Overall fuel consumption and $\mathrm{CO}_{2}$ results (HEV topologies vs. ICE concepts)

TABULKA 5: Celkové výsledky spotřeb paliva a produkce $\mathrm{CO}_{2}$ (topologie $\mathrm{HEV}$ vs. koncepty spalovacích motorů)

\begin{tabular}{|c|c|c|c|c|c|c|c|c|}
\hline & ICE & $\begin{array}{c}\text { CS mode } \\
\text { FC } \\
{[\mathrm{L} / 100 \mathrm{~km}]}\end{array}$ & $\begin{array}{c}\text { CS mode } \\
\mathrm{CO}_{2} \\
{[\mathrm{~g} / \mathrm{km}]}\end{array}$ & $\begin{array}{l}\text { AER } \\
{[\mathrm{km}]}\end{array}$ & $\begin{array}{l}\text { UF } \\
{[-]}\end{array}$ & $\begin{array}{c}\text { Combined } \\
\text { FC } \\
{[\mathrm{L} / 100 \mathrm{~km}]}\end{array}$ & $\begin{array}{c}\text { Combined } \\
\mathrm{CO}_{2} \\
{[\mathrm{~g} / \mathrm{km}]}\end{array}$ & $\begin{array}{c}\text { Combined } \\
\Delta \mathrm{CO}_{2} \\
{[\mathrm{~g} / \mathrm{km}]}\end{array}$ \\
\hline \multirow{3}{*}{ P2W } & $2.0 \mathrm{NA}$ & 4.446 & 101.37 & 62.5 & 0.777 & 0.989 & 22.56 & -116.86 \\
\hline & $1.5 \mathrm{TC}$ & 4.618 & 105.29 & 62.2 & 0.777 & 1.028 & 23.43 & -108.28 \\
\hline & $1.0 \mathrm{TC}$ & 4.438 & 101.19 & 62.3 & 0.777 & 0.988 & 22.52 & -97.20 \\
\hline \multirow{3}{*}{ P3 } & $2.0 \mathrm{NA}$ & 4.273 & 97.42 & 56.1 & 0.753 & 1.058 & 24.11 & -115.31 \\
\hline & $1.5 \mathrm{TC}$ & 4.506 & 102.74 & 53.6 & 0.734 & 1.198 & 27.32 & -104.40 \\
\hline & $1.0 \mathrm{TC}$ & 4.378 & 99.82 & 55.0 & 0.753 & 1.084 & 24.70 & -95.02 \\
\hline \multirow{3}{*}{ P4 } & $2.0 \mathrm{NA}$ & 4.213 & 96.06 & 66.4 & 0.777 & 0.938 & 21.38 & -118.05 \\
\hline & $1.5 \mathrm{TC}$ & 4.364 & 99.50 & 66.7 & 0.777 & 0.971 & 22.14 & -109.57 \\
\hline & $1.0 \mathrm{TC}$ & 4.293 & 97.88 & 66.9 & 0.777 & 0.955 & 21.78 & -97.94 \\
\hline
\end{tabular}

much better for the P4. The difference comes mainly from the much more favorable total gear ratio for the P4, together with better efficiencies in EV mode. The comparison of EM operating points in figure 5 indicates, that the EM in P3 topologies spends a lot of time in low speed - high torque regions; the P4 gear ratio on the other hand allows for generally higher EM operating speeds with better overall efficiencies.
A natural expectation for the P2 topology is, that it would use the ability to shift gears also in EV mode to offset the transmission efficiency disadvantage (compared for instance to P3 or P4). However, for the case of overall results, the gear shifting strategy comes from WLTP - generated based on ICE performance, not EMs - which proves to be problematic. It is once again in full display in figure 5 with EM operating points,
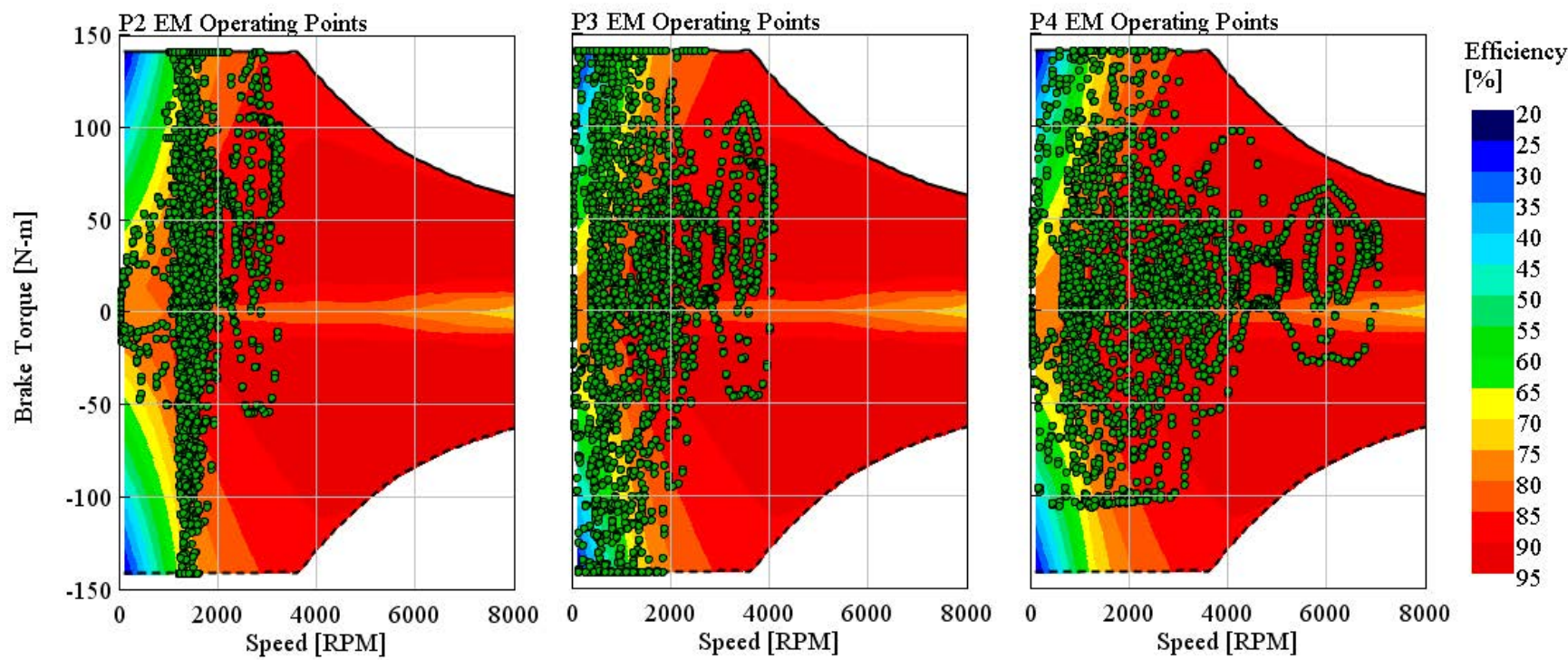

FIGURE 5: EM operating points in WLTC, driven in EV mode

OBRÁZEK 5: Pracovní body elektromotoru v jízdním cyklu WLTC, v elektrickém módu 


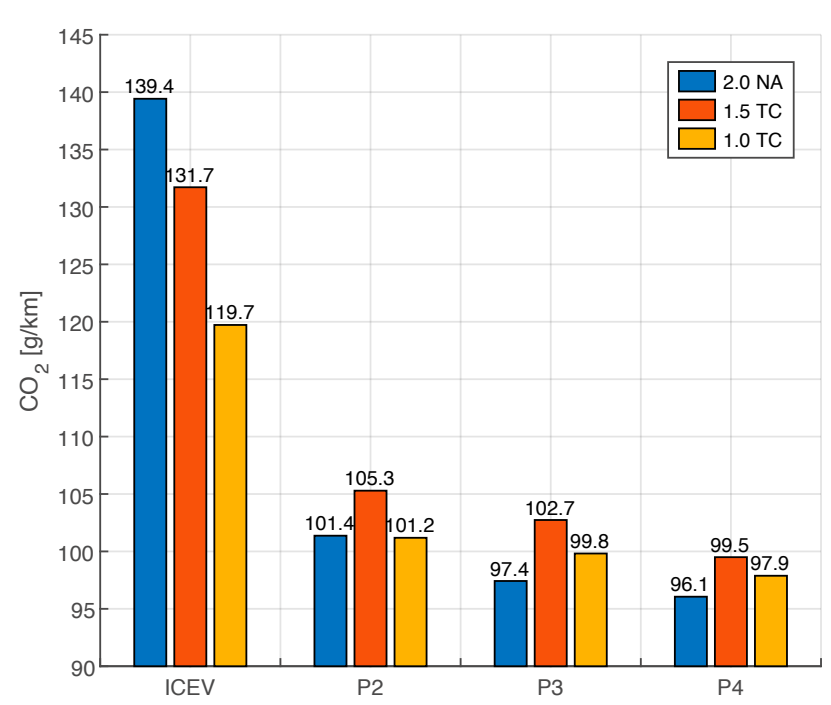

FIGURE 6: Overall CS mode $\mathrm{CO}_{2}$ results (topologies vs. ICE concepts)

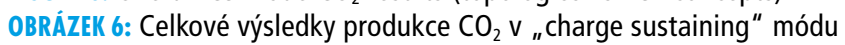
(topologie HEV vs. koncepty spalovacích motorů)

where the EM operating points for P2 are "compressed" to the low speed regions with lower efficiencies.

Figure 6 depicts the $\mathrm{CS}$ mode $\mathrm{CO}_{2}$ values only, and gives us another interesting observation, that the best CS mode results are achieved with $2.0 \mathrm{NA}$ concept and not with the turbocharged concepts: there is no synergy effect between the powertrain hybridization and ICE downsizing. The explanation lays in the BSFC maps: $2.0 \mathrm{NA}$ best value is $12.8 / 13.7 \mathrm{~g} / \mathrm{kWh}$ better compared to $1.5 \mathrm{TC}$ and $1.0 \mathrm{TC}$ respectively. $\mathrm{CO}_{2}$ value for 1.0 TC in ICEV powertrain is already very good, thus it's hybridization CS mode potential in all PHEV topologies is the smallest. However, for 1.5 TC versus 1.0 TC comparison the downsizing effect is lowered by the effect of powertrain hybridization.

From the vehicle homologation perspective, these CS mode sensitivities do not play any role. The only important result is the combined $\mathrm{CO}_{2}$ values from the table 5 , where the WLTP calculation clearly prefers the AER before the CS mode. However, the CS mode results could be interesting from the point of view of the OEMs: cheaper, higher-displacement ICEs, hybridized in a clever way can bring some economic benefits.

\subsection{P2 SENSITIVITY ON GEAR SHIFTING}

The overall results from the above chapter showed P2 fuel consumption using WLTP generated gear shifting points. Further gear shifting optimization using DP algorithm for the $\mathrm{P} 2$ topology in $\mathrm{CS}$ mode shows another $\mathrm{CO}_{2}$ potential ("DP-optimized" in and figure 7) in comparison to the WLTP shifting strategy.

The 1.5 TC and 2.0 NA concept achieve a very similar additional $\mathrm{CS}$ mode $\mathrm{CO}_{2}$ improvement (both at $\sim 10 \mathrm{gCO}_{2} / \mathrm{km}$ ), and the 1.0 $T C$ only $\sim 5 \mathrm{gCO}_{2} / \mathrm{km}$.

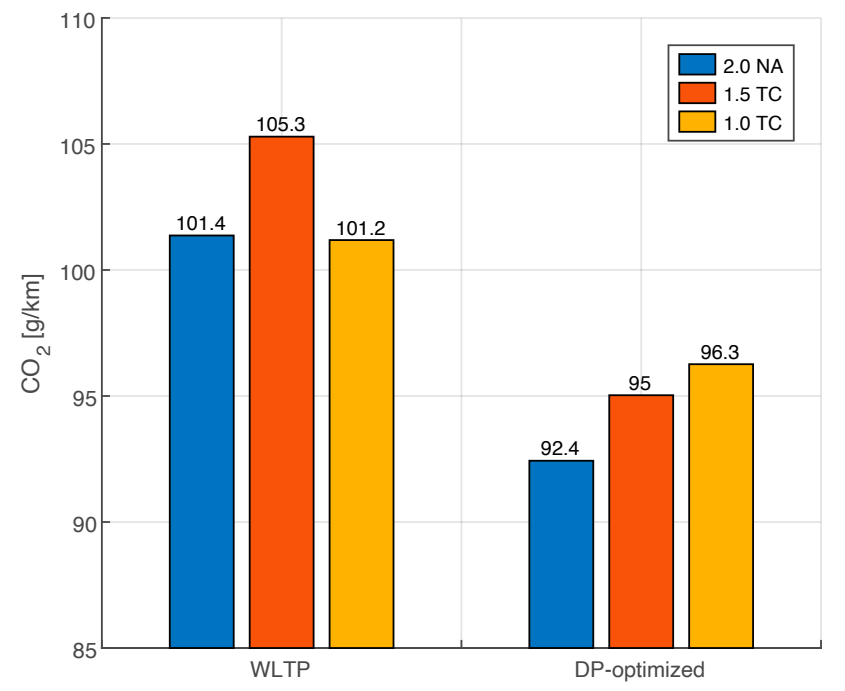

FIGURE 7: P2 topology $\mathrm{CO}_{2}$ sensitivity on gear shifting OBRÁZEK 7: $\mathrm{CO}_{2}$ citlivost topologie $\mathrm{P} 2$ na prủběh řazení

We did not calculate the further $\mathrm{CO}_{2}$ potential from the homologation perspective, because this requires also the AER simulation with optimized gear shifting strategy. However, the CS mode improvement indicates, that the AER results will also be improved, leading to even lower homologation $\mathrm{CO}_{2}$ values. Concluding this sensitivity, it is important to once again stress, that 2.0 NA concept still proves having the highest hybridization potential.

\subsection{DP VS. ECMS CONTROL STRATEGY SENSITIVITY}

This next sensitivity compares ECMS and DP algorithms' performance. Figure 8 shows three of the nine total combinations

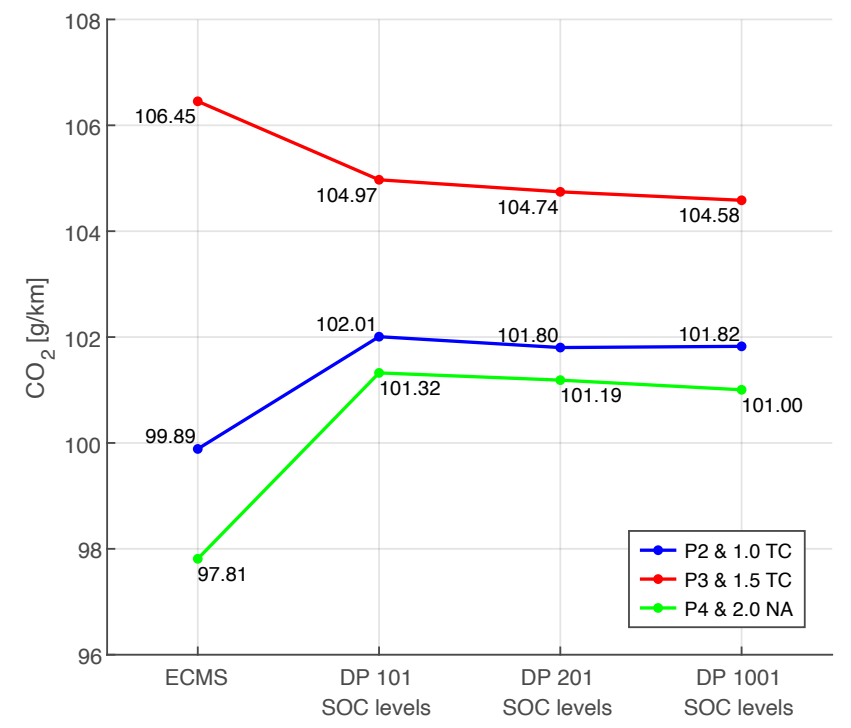

FIGURE 8: Control strategy $\mathrm{CO}_{2}$ sensitivity in $\mathrm{CS}$ mode OBRÁZEK 8: $\mathrm{CO}_{2}$ citlivost řídících strategií v "charge sustaining" módu 
of HEV topology and ICE concept. All the results use the same $E V_{\text {lim }}$ parameter of $77 \mathrm{~km} / \mathrm{h}$. For the ECMS results, we had to calibrate the equivalence factor $s$ for each of the simulations to reach the CS cycle; for the DP simulations we have tried different SOC resolutions, starting with $1 \%$ of the SOC span (defined by the $S O C_{\max }$ and $S O C_{\min }$ values), that divides the SOC span to 101 SOC levels. The $0.5 \%$ resolution uses 201 levels, and $0.1 \% 1001$ levels. Higher number of SOC level leads to results closer to global optimum, but also the simulation times are longer: $0.1 \%$ resolution leads to approximately 10-times longer simulation than $1 \%$.

However, a look on figure 8 reveals, that the GT-Suite's ECMS implementation performs better than DP implementation for two of the three topologies (results are consistent for all ICE concepts). The only case when the DP is closer to a global optimum are the $\mathrm{P} 3$ topology results. Differences of $\mathrm{FC} / \mathrm{CO}_{2}$ are in favor of ECMS for the P2 ( 2\%), and P4 ( 4\%), and in favor of the DP $(\sim 1.5 \%)$ for the case of P3 topology.

It is also important to note, that the procedure of finding the CS equivalence factor $s$ requires an iterative process - usually 20-40 simulations. It takes approximately the same simulation time to reach the CS results with ECMS, as to simulate one DP run with $1 \%$ SOC resolution.

The first reason for the rather unexpected result for the $\mathrm{P} 2$ and P4 topologies can be the way how the ECMS and DP use their penalty functions: it is possible, that using the same formulation of penalty functions, or not using any at all, could

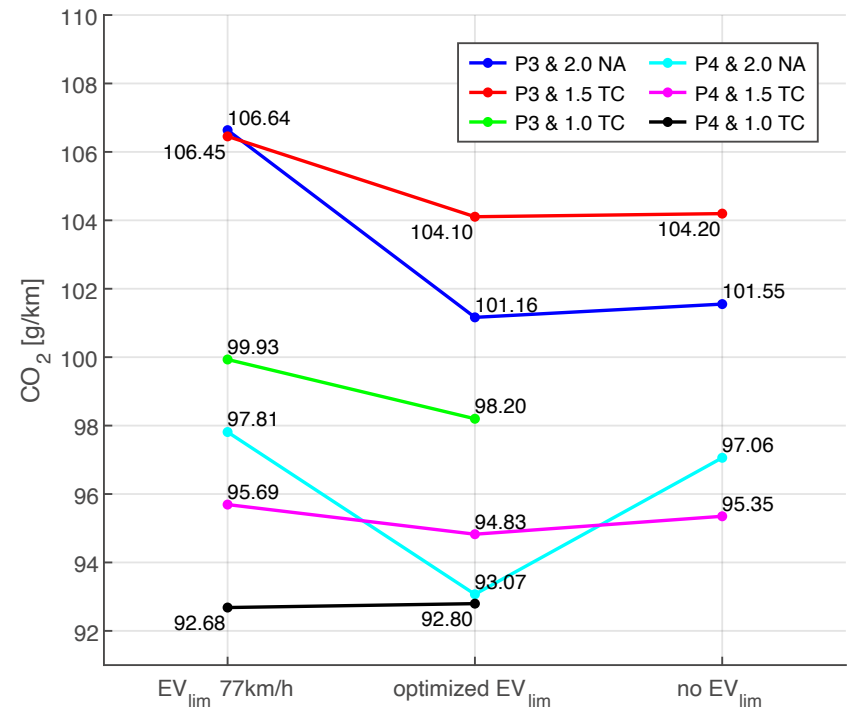

FIGURE 9: ECMS control strategy $\mathrm{CO}_{2}$ sensitivity on heuristic parameter $E V_{\text {lim }}$ in CS mode

OBRÁZEK 9: $\mathrm{CO}_{2}$ citlivost řídící strategie ECMS na heuristický parametr $E V_{\text {lim }} \mathrm{v}$ "charge sustaining" módu

resolve the difference. The second possible reason is the different sensitivities of both methods on control variables, that were set-up the same way in our simulations.

However, from the user point of view, the simulations with DP algorithm may take more time, and not always reach the global optima "as advertised", but they may be more comfortable to work with, since they do not require the iterative process of

TABLE 6: Acceleration results for $2.0 \mathrm{NA}$ concept and all HEV topologies

TABULKA 6: Akcelerace pro koncept spalovacího motoru 2.0 NA a všechny HEV topologie

\begin{tabular}{|c|c|c|c|c|c|c|c|c|}
\hline \multirow[t]{2}{*}{ Mode } & \multirow[t]{2}{*}{ Topology } & \multirow[t]{2}{*}{$0-100 \mathrm{~km} / \mathrm{h}[\mathrm{s}]$} & \multicolumn{2}{|c|}{$60-80 \mathrm{~km} / \mathrm{h}[\mathrm{s}]$} & \multicolumn{2}{|c|}{$60-100 \mathrm{~km} / \mathrm{h}[\mathrm{s}]$} & \multicolumn{2}{|c|}{$80-120 \mathrm{~km} / \mathrm{h}[\mathrm{s}]$} \\
\hline & & & Gear 5 & Gear 6 & Gear 5 & Gear 6 & Gear 5 & Gear 6 \\
\hline \multirow{3}{*}{ HEV } & P2 & 5.1 & 3.1 & 3.7 & 5.8 & 7.2 & 5.8 & 7.4 \\
\hline & P3 & 6.3 & 3.0 & 3.2 & 5.6 & 6.3 & 5.6 & 6.5 \\
\hline & P4 & 5.8 & 2.4 & 2.5 & 4.8 & 5.3 & 5.4 & 6.1 \\
\hline \multirow{3}{*}{ ICEV } & P2 & 8.2 & 5.7 & 7.0 & 10.9 & 14.1 & 10.7 & 14.5 \\
\hline & P3 & 8.1 & 5.7 & 7.0 & 10.9 & 14.1 & 10.7 & 14.5 \\
\hline & P4 & 8.3 & 5.8 & 7.1 & 11.1 & 14.4 & 10.9 & 14.8 \\
\hline \multirow{3}{*}{ EV } & P2 & 15.8 & 7.1 & 9.3 & 15.3 & 19.4 & 16.9 & 22.2 \\
\hline & P3 & 32.2 & 6.9 & 6.8 & 14.0 & 14.0 & 15.4 & 15.4 \\
\hline & P4 & 20.3 & 4.1 & 4.1 & 9.6 & 9.6 & 13.7 & 13.7 \\
\hline
\end{tabular}


equivalence factor $s$ calibrations. The crucial fact is, that the results for both the ECMS and DP GT-Suite implementations are qualitatively the same (general behavior is the same with all ICE concepts and HEV topologies), although quantitatively there are some differences.

\subsection{ECMS SENSITIVITY ON MAXIMUM VEHICLE SPEED IN EV MODE}

The last set of CS mode simulations is the ECMS control method sensitivity on the $E V_{\text {lim }}$ parameter. Similarly, as for the penultimate sensitivity in chapter 4.4, we show only some of the results.

The optimized $E V_{\text {lim }}$ values generally achieve the best $\mathrm{CO}_{2}$ results (figure 9). But, the sensitivity of all ICE concept and HEV topology combinations in CS mode vary:

- P4 topology with 1.0 TC concept, and all the P2 combinations are not able to reach the CS mode in simulations with $E V_{\text {lim }}$ parameter turned off (explanation in chapter 3.4);

- $2.0 \mathrm{NA}$ concept - for all topologies - achieves the best results using $E V_{\text {lim }}$ above $100 \mathrm{~km} / \mathrm{h}$;

- P3 topology also achieves the best results using $E V_{\text {lim }}$ above $100 \mathrm{~km} / \mathrm{h}$ - for all ICE concepts;

- 1.0 TC concept uses relatively low $E V_{\text {lim }}$ values in combination with P2 and P4 topologies;

- P4 topology's optimal $E V_{\text {lim }}$ values decrease with increasing ICE downsizing level;

- The lowest sensitivity of all combinations is for P4 topology with $1.5 \mathrm{TC}$ concept, where the $\mathrm{CO}_{2}$ results change only around one $\mathrm{gCO}_{2} / \mathrm{km}$.

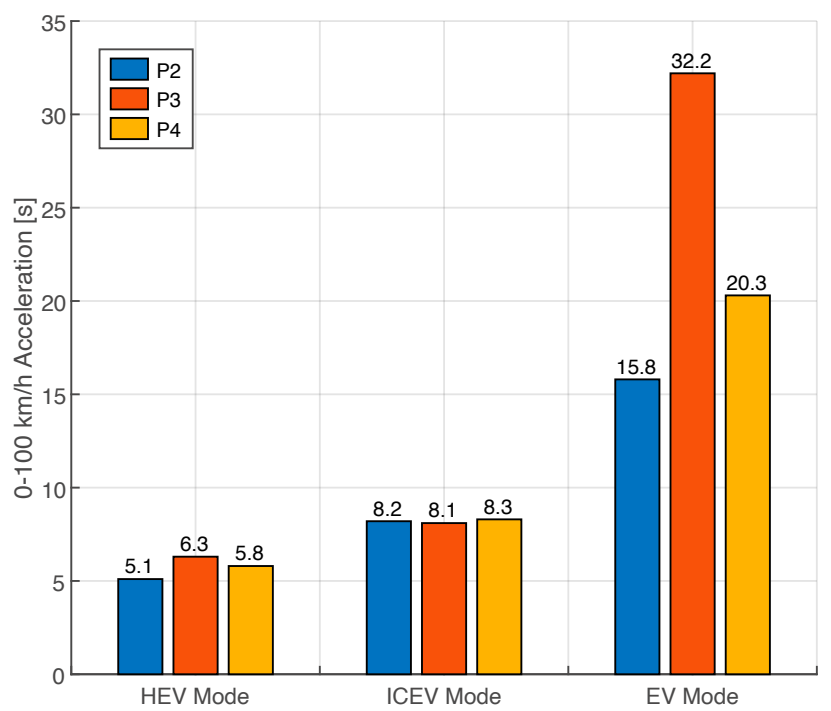

FIGURE 10: 0-100 km/h acceleration for $2.0 \mathrm{NA}$ concept and all HEV topologies

OBRÁZEK 10: Zrychlení 0-100 km/h pro koncept motoru $2.0 \mathrm{NA}$ a všechny HEV topologie

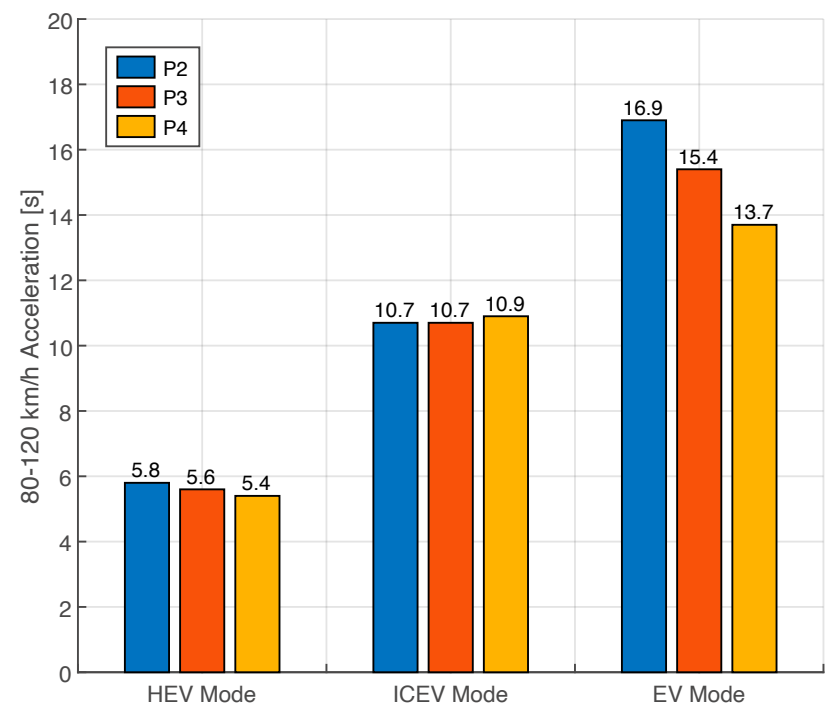

FIGURE 11: 80-120 km/h acceleration for $2.0 \mathrm{NA}$ concept and all HEV topologies, at $5^{\text {th }}$ gear

OBRÁZEK 11: Zrychlení 80-120 km/h pro koncept motoru 2.0

$N A$ a všechny HEV topologie, na 5 . prevodový stupeň

Finally, for some combinations, the $E V_{\text {lim }}$ optimization can bring up to $5 \mathrm{gCO}_{2} / \mathrm{km}$ potential.

\subsection{OVERALL VEHICLE DYNAMICS RESULTS}

We have prepared several vehicle dynamics scenarios to compare the different hybridization variants: acceleration of $0-100 \mathrm{~km} / \mathrm{h}$, $60-80 \mathrm{~km} / \mathrm{h}, 60-100 \mathrm{~km} / \mathrm{h}$, and $80-120 \mathrm{~km} / \mathrm{h}$, and the maximum vehicle speed simulation. We have simulated all HEV powertrain and ICE concept combination; however, here we present only the

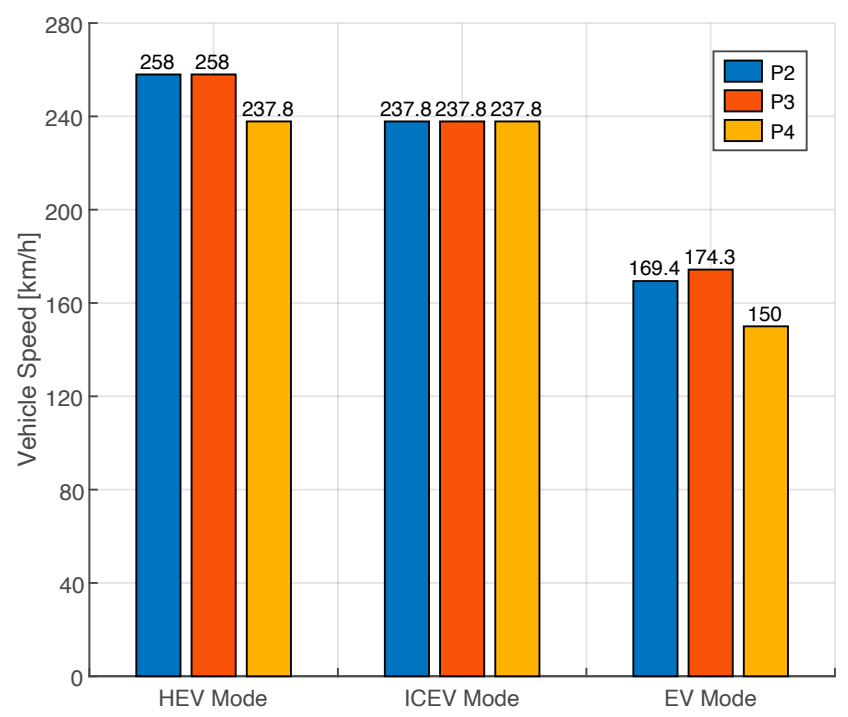

FIGURE 12: Maximum vehicle speed for $2.0 \mathrm{NA}$ concept and all HEV topologies in different driving modes

OBRÁZEK 12: Maximální rychlost vozidla pro koncept motoru 2.0 $N A$ a všechny HEV topologie a jízdní módy 
2.0 NA concept results, as the map-based approach does not capture well the dynamic effects of turbocharged ICE concepts 1.0 TC, and 1.5 TC-as it was discussed in chapter 3.1. The P2, $\mathrm{P} 3$, and $\mathrm{P} 4$ topologies are compared in three different modes: hybrid (HEV), conventional (ICEV), and pure electric (EV).

\subsubsection{ACCELERATION RESULTS}

The acceleration tests consist of $0-100 \mathrm{~km} / \mathrm{h}$ acceleration, and then the tests of $60-80 \mathrm{~km} / \mathrm{h}, 60-100 \mathrm{~km} / \mathrm{h}$, and $80-120 \mathrm{~km} / \mathrm{h}$ accelerations at the $5^{\text {th }}$ and $6^{\text {th }}$ gear, for all driving modes (HEV, ICEV, EV). The gear shifting strategy for 0-100 km/h acceleration considers the maximum ICE or EM speed. All acceleration results are listed in table 6, and shown in figures 10, and 11.

The P2 topology achieves the best $0-100 \mathrm{~km} / \mathrm{h}$ acceleration in combined HEV mode, followed by the P4, and P3 topologies (figure 10). The case of EV acceleration shows the same order in topologies' performance: the best result is achieved by the P2, followed by P4, and finally P3. The ICEV 0-100 $\mathrm{km} / \mathrm{h}$ accelerations are the only accelerations, where the variation is very low: all achieve results around 8.2 seconds. The HEV and EV results are strongly influenced by the gear ratios available for the EM: the $\mathrm{P} 2$ topology can shift gears, whereas the P3, and P4 can only make use of single gear, which is more beneficial for P4. Finally, the EV accelerations are logically also limited by the maximum EM power.

The rest of the table 6 contains the other accelerations at constant gear: sensitivities $60-80 \mathrm{~km} / \mathrm{h}, 60-100 \mathrm{~km} / \mathrm{h}$, and $80-120 \mathrm{~km} / \mathrm{h}$, both on $5^{\text {th }}$ gear, and $6^{\text {th }}$ gear; all for $2.0 \mathrm{NA}$ engine concept. The $80-120 \mathrm{~km} / \mathrm{h}$ scenario at $5^{\text {th }}$ gear is shown in figure 11 .

Also, these results are influenced mostly by the total gear ratios for different machines (ICE, EM): the P4 topology performs consistently as the best for both the HEV and EV acceleration modes, and P2 as the worst; the ICEV accelerations show very little sensitivity, because the only differences are the drivetrain efficiencies, and vehicle masses. The biggest variation happens again in case of EV acceleration mode, as the topologies vary greatly in their final gear ratios.

The $6^{\text {th }}$ gear acceleration modes are qualitatively the same as on $5^{\text {th }}$ gear.

\subsubsection{MAXIMUM VEHICLE SPEED}

The final test is the vehicle maximum speed, which depends mainly on the maximum total powertrain power, available for different driving modes (figure 12). The combined HEV maximum speed is transmission range limited and exceeds the vehicle speeds of $250 \mathrm{~km} / \mathrm{h}$ for both the P2 and P3 topology. The P4 maximum HEV speed is in this case the same as for ICEV driving mode, due to P4 electric motor speed limit, as the EM is declutched above $150 \mathrm{~km} / \mathrm{h}$, and therefore not providing power. The ICEV maximum speeds are all around $238 \mathrm{~km} / \mathrm{h}$.

Finally, the maximum achievable EV speeds are all limited by the EM maximum power of $54 \mathrm{~kW}$, the $\mathrm{P} 3$ performing better then P2 topology. P4 maximum EV speed is also limited by abovementioned EM speed limit, that is bound to the rear axle gear ratio design.

\section{CONCLUSIONS}

Our paper presents a full development and benchmarking methodology for HEV powertrains, that is built on GT-Suite simulation software platform. The methodology consists of a combination of vehicle $\mathrm{CO}_{2}$ homologation simulations (using WLTP methodology), and some vehicle dynamics tasks (different accelerations test, and maximum vehicle speed test).

We have prepared HEV simulation models using two different simulation approaches: a backward-kinematic approach (KIN models), and a dynamic approach (DYN models). Our KIN models are combined with GT-Suite's built-in optimal energy management control methods ECMS and Dynamic Programming (DP). Both KIN and DYN models were then used for the $\mathrm{CO}_{2}$ WLTP homologation studies, obtaining Charge Sustaining (CS) $\mathrm{CO}_{2}$, and All Electric Range (AER) results, together with the already mentioned additional vehicle dynamics results.

The whole presented methodology was tested on three different HEV topologies (P2, P3, and P4) in combination with three different ICE concepts (2.0 NA, 1.5 TC, and 1.0 TC), at the same hybridization level (with $P_{I C E}$ of $135 \mathrm{~kW}$ and $P_{E M}$ of $54 \mathrm{~kW}$ ), using a six-speed transmissions, for a C-class plug-in HEV with a $14.8 \mathrm{kWh}$ high voltage battery. All combinations show very good results compared to conventional powertrain, either in $\mathrm{CO}_{2}$ homologation tests, or in vehicle dynamics tests:

- ICEV comparison of the three ICE concepts with different downsizing levels reveal a well-known fact, that downsized engines perform better in homologation driving cycles, such as WLTC;

- Total $\mathrm{CO}_{2}$ reduction potentials from ICEV to PHEV homologation $\mathrm{CO}_{2}$ values are similar for all powertrains, ranging from -95 to $-119 \mathrm{gCO}_{2} / \mathrm{km}$;

- The first part of the homologation are the AER tests, that show greater potentials for P4 and P2 HEV variants, since these use the EM in a more efficient manner, reaching AER values of $\sim 66.7 \mathrm{~km}$ (P4), $\sim 62.3 \mathrm{~km}$ (P2). However, the P3 also achieves high AER values of $\sim 54.9 \mathrm{~km}$;

- The second part of the homologation are the CS tests, where the different HEV powertrain combinations 
reach $\mathrm{CO}_{2}$ reduction potentials from -22 to $-45 \mathrm{gCO}_{2} /$ $\mathrm{km}$ (using DP control method);

- The P4 powertrains perform the best in the CS tests, together with the 2.0 NA ICE concept - on the other end of the results were the $\mathrm{P} 2$ topology, and the 1.5 TC concept;

- The P2 topology CS results can be further improved by the gear shifting strategy optimization: bringing additional $\sim 5-10 \mathrm{gCO}_{2} / \mathrm{km}$ improvement, beating the abovementioned $\mathrm{P} 4$ results;

- The vehicle $0-100 \mathrm{~km} / \mathrm{h}$ acceleration tests show the biggest performance benefit for $\mathrm{P} 2$ - that shifts gears also for the EM - followed by the P4, and then P3;

- The P4 topology then performs best at constant gear vehicle acceleration tests, followed by the $\mathrm{P} 3$, and $\mathrm{P} 2$.

There are three main conclusions from the PHEV homologation and vehicle dynamics studies:

1. There is no synergy effect between the powertrain hybridization and ICE downsizing, the trend seems to be rather opposite: $2.0 \mathrm{NA}$ concept is reaching the highest $\mathrm{CO}_{2}$ reduction potentials;

2. It is valuable to optimize the HEV topology having the ICE concept in mind; however, the current PHEV homologation favors the AER, which may discourage developments in this area: the "simple" addition of a large enough battery (with AER of $50 \mathrm{~km}$ ), reduces the homologation $\mathrm{CO}_{2}$ by $90 \mathrm{gCO}_{2} / \mathrm{km}$ or more;

3. The vehicle dynamics tests further stress the importance of holistic HEV powertrain optimization: especially the transmissions gear ratios, with the goal of getting the best also out of the EM operation.

Apart from the overall homologation $\mathrm{CO}_{2}$ and vehicle dynamics studies, we have also tested the performance of the GT-Suite's implementations of ECMS and DP optimal control methods:

- DP control method is generally more computationally demanding, but offers a user advantage of not having to calibrate for a correct equivalence factor to reach a CS cycle condition, as for the ECMS method;

- Rather surprising result of the comparison of these two control methods in GT-Suite is, that in some cases the ECMS can reach values closer to the theoretical global optimum compared to DP method, which is "advertised" as the globally optimal control method;

- However, both methods are consistent, providing qualitatively the same results, showing similar trends;

- Both methods are sensitive on their settings: in the case of DP it is the discretization of control inputs, and of state variable; ECMS is sensitive on the equivalence factor;

- Additional heuristic parameters help ensure the CS convergence of ECMS method and can further improve the $\mathrm{CO}_{2}$ results.
Our further work will focus mainly on two areas: first is the amplification of the HEV model database - adding more HEV topologies; and second, embedding our simulation methodology into a multi-parametric and multi-objective HEV powertrain optimization strategy.

\section{ACKNOWLEDGEMENTS}

This work was realized using support of:

- Technological Agency, Czech Republic, programme National Competence Centres, project \# TN01000026 Josef Bozek National Center of Competence for Surface Vehicles.

- The Grant Agency of the Czech Technical University in Prague, grant No. SGS19/104/OHK2/2T/12.

This support is gratefully acknowledged.

\section{LIST OF NOTATIONS AND ABBREVIATIONS}

AER All Electric Range

AWD All-wheel drive

BSFC Brake-specific fuel consumption

CAE Computer Aided Engineering

$\mathrm{CD} \quad$ Charge Depleting

$\mathrm{CO}_{2} \quad$ Carbon dioxide

CS Charge Sustaining

DP Dynamic Programming

DYN Dynamic model

ECMS Equivalent Consumption Minimization Strategy

ECU Engine Control Unit

EM Electric motor

EV Electric Vehicle

FC Fuel Consumption

FWD Front-wheel drive

GT Gamma Technologies

HEV Hybrid electric vehicle

HV High voltage

ICE Internal combustion engine

ICEV Internal Combustion Engine Vehicle

KIN Kinematic model

LPS Load Point Shifting

NA Naturally aspirated

OEM Original Equipment Manufacturer

OVC-HEV Off-Vehicle Charging Hybrid Electric Vehicle

PHEV Plug-In Hybrid Electric Vehicle

PMP Pontryagin's minimum principle

RDE Real Driving Emissions

RPM Revolutions per minute

SOC State of Charge

TC Turbocharged

UF Utility Factor 
Variable valve timing

WLTC Worldwide Harmonized Light-Duty Vehicles Test Cycle

WLTP Worldwide Harmonized Light-Duty Vehicles Test Procedure

\section{REFERENCES}

[1] Reducing $\mathrm{CO}_{2}$ emissions from passenger cars. European Commission, online, cited: 2019-06-31, accessed from: https://ec.europa.eu/clima/policies/transport/vehicles/ cars_en

[2] Sundström, O., Guzzella, L., Soltic, P. (2008). Optimal Hybridization in Two Parallel Hybrid Electric Vehicles using Dynamic Programming, IFAC Proceedings Volumes, 41, 2: $4642-4647$

[3] Lodaya, D., Zeman, J., Okarmus, M., Mohon, S., et al. (2020). Optimization of Fuel Economy Using Optimal Controls on Regulatory and Real-World Driving Cycles, SAE Int. J. Advances \& Curr. Prac. in Mobility 2(3):1705-1716, 2020, doi:10.4271/2020-01-1007.

[4] Guzzela, L., Sciaretta, A. Vehicle Propulsion Systems: Introduction to Modelling and Optimization, Springer, 2013, ISBN 978-3-642-35913-2

[5] Biasini, R., Onori, S., Rizzoni, G. (2013). A near-optimal rule-based energy management strategy for medium duty hybrid truck, Int. J. Powertrains, Vol. 2, Nos. 2/3: 232-261

[6] Zhou, H., Xu, Z., Liu, L., Liu, D., Zhang, L. (2018). A Rule-Based Energy Management Strategy Based on Dynamic Programming for Hydraulic Hybrid Vehicles, Hindawi Mathematical Problems in Engineering, Vol. 2018, doi:10.1155/2018/9492026

[7] Shen, W., Yu, H., Hu, Y., Xi, J. (2016). Optimization of Shift Schedule for Hybrid Electric Vehicle with Automated Manual Transmission, Energies 2016, 9, 220, doi:10.3390/en9030220

[8] Wang, R., Lukic, S. (2012) Dynamic Programming Technique in Hybrid Electric Vehicle Optimization, IEEE Xplore, doi: 10.1109/IEVC.2012.6183284

[9] Zeng, Y., Sheng, J., Ming, L. (2018). Adaptive Real-Time Energy Management Strategy for Plug-In Hybrid Electric Vehicle Based on Simplified-ECMS and a Novel Driving Pattern Recognition Method, Mathematical Problems in Engineering, p. 1-12, doi:10.1155/2018/5816861

[10]Nüesch, T., Cerofolini, A., Mancini, G., Cavina, N., Onder, Ch., Guzzella, L. (2014). Equivalent Consumption Minimization Strategy for Control of Real Driving NOx Emissions of a Diesel Hybrid Electric Vehicle, In: Energies 2014, vol. 7, p. 3148-3178, doi:10.3390/en70532148
[11]Yuan, Z., Teng, L., Fengchun, S., Peng, H. (2013). Comparative Study of Dynamic Programming and Pontryagin's Minimum Principle on Energy Management for a Parallel Hybrid Electric Vehicle, Energies 2013, 6, 2305-2318, doi:10.3390/en6042305

[12]Zeman, J., Papadimitriou, I., Watanabe, K., Kubo, M., Kumagai, T. (2012). Modeling and Optimization of PlugIn Hybrid Electric Vehicle Fuel Economy, SAE Technical Paper 2012-01-1018, doi:10.4271/2012-01-1018

[13]Bellman, R. (1966). Dynamic Programming, Science, vol. 153 , no. 3731, pp. 34-37.

[14] UN Global Technical Regulation No. 15: Worldwide harmonized Light vehicles Test Procedure (ECE/ TRANS/180/Add.15). United Nations Economic Commission for Europe, 2019-06-26, cited: 2020-11-01, accessed from: https://www.unece.org/fileadmin/DAM/ trans/main/wp29/wp29wgs/wp29gen/wp29registry/ECETRANS-180a15am5e.pdf 